\title{
Growth and Yield of Chili Pepper as Affected by Weed Based Organic Compost and Nitrogen Fertilizer
}

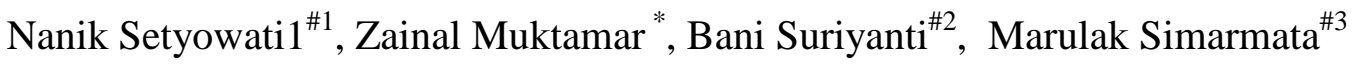 \\ \# Agronomy Department, University of Bengkulu, Bengkulu 38371, Indonesia \\ E-mail: ' nanik_srg@yahoo.com, ${ }^{2}$ bannyagroa@gmail.com, ${ }^{3}$ marulak_simarmata@yahoo.com \\ * Soil Science Department, University of Bengkulu, Bengkulu 38371, Indonesia \\ E-mail: muktamar1959@yahoo.com
}

\begin{abstract}
Fertility improvement of Ultisol is inevitable to increase growth and yield of chili pepper since the nutrient availability and organic matter of this soil is relatively low. Application of organic fertilizer will enhance microorganism activity in soil, thereafter will improve the availability of nutrients as well as other chemical, physical, biological properties of the soil. Most of manure releases nutrient quite slowly; therefore, addition of nitrogen to soil is expected to speed up the availability of nutrient to plant. Weed based organic fertilizers from Wedelia (Wedelia trilobata) and Siam weed (Chromolaena odorata) biomass have potential to substitute inorganic fertilizer. The objective of the experiment was to compare the effects of weed based organic compost and dry leaves compost with or without addition of nitrogen fertilizer on growth and yield of chili pepper. The experiment was carried out using Completely Randomized Design (CRD) with treatments of $200 \mathrm{~kg}$ urea ha-1; Wedelia compost (WDC) 20 ton ha-1; WDC 15, 10, and 5 ton ha-1 with addition of $200 \mathrm{~kg}$ urea ha-1 respectively; Siam weed compost (SWC) 20 ton ha-1, SWC 15, 10, and 5 ton ha-1 with addition of $200 \mathrm{~kg}$ urea ha-1 respectively; and dry leaves compost (DLC) 20 ton ha-1, DLC 15, 10, and 5 ton ha-1 with addition of 200 $\mathrm{kg}$ urea ha-1 respectively. The result revealed that composts with or without addition of nitrogen fertilizer had similar responses on the growth of chili pepper. Wedelia and Siam weeds compost at 20 ton ha-1 tended to give better yield of chili pepper as compared to application of urea alone. This result indicated that weed based organic fertilizers could substitute nitrogen fertilizer.
\end{abstract}

Keywords - Wedelia, Siam weed, Wedelia trilobata, Chromolaena odorata, manure.

\section{INTRODUCTION}

It is commonly found that Ultisol has low fertility due to low availability of major nutrients for plant growth as well as high solubility of aluminum in soil solution and low organic matter. According to [1] and [2] Ultisol is commonly acid, has low soil organic matter, Cation Exchange Capacity (CEC), and availability of nutrient required for plant growth as well as high aluminum saturation in soil solution. This soil milieu will hinder the growth and development of chili pepper.

Improvement of Ultisol is necessary to provide better growing environment of chili pepper and addition of organic matter to soil will step up the fertility. Experiment conducted by [3] showed that application of compost improved soil quality. Improvements were seen in higher total carbon, decreased bulk density, enhanced microbial activity, total nitrogen, water holding capacity, and water infiltration rate. Soil amended with compost generally provided similar available plant nutrient to that managed conventionally. Another study by [4] revealed that high rate of compost application significantly increased soil organic matter and available $\mathrm{P}$ and $\mathrm{K}$ than application of inorganic $\mathrm{N}$ fertilizer. In addition, application of compost to soil also increased plant defense ability against pathogens [5]. Fine textured compost generally has greater effect on soil properties and plant growth as compared to that with coarse textured compost [6]. Higher quality dairy manure compost, however, does not give significant differences corn yield [7].

Nutrient release from organic matter is usually slow [8], therefore, addition of nitrogen to soil is expected to accelerate the availability of nutrients to plant. Study by [9] revealed that concentration phosphorus in soil increased significantly when application of compost was supplemented with nitrogen fertilizer, indicating that additional nitrogen enhanced mineralization of organic matter.

Organic matter can be derived from compost of animal and plant wastes. Selected weeds such as water hyachinth (Eichornia crassipes) [10], Wedelia (Wedelia trilobata) [11], Siam weed (Cromolaena ordota) [12] have potential as sources of organic compost. Study by [13] showed that Wedelia compost had higher carbon, calcium, magnesium, potassium, and nitrogen content than cattle manure. Siam 
weed also has substantial amount of biomass with nutrients content of $49.97 \%$ C-organic, $3.04 \%$ total N, $0.29 \%$ P, and $9.00 \%$ lignin [14]. The objective of the experiment was to compare the effects of weed based organic compost and dry leaves compost with or without addition of nitrogen fertilizer on growth and yield of chili pepper.

\section{MATERIALS AND MethodS}

\section{A. Experimental Design and Treatment}

Greenhouse experiment was conducted in Pematang Gubernur Village of Bengkulu, Indonesia. The experiment was carried out using Completely Randomized Design (CRD) with 13 treatments as follows:

$\mathrm{T}-1=200 \mathrm{~kg}$ urea ha-1

$\mathrm{T}-2=$ Wedelia compost (WDC) 20 ton ha- 1

$\mathrm{T}-3=$ WDC 15 ton ha- $1+200 \mathrm{~kg}$ urea ha-1

T-4 = WDC 10 ton ha- $1+200 \mathrm{~kg}$ urea ha-1

$\mathrm{T}-5=\mathrm{WDC} 5$ ton ha- $1+200 \mathrm{~kg}$ urea ha-1

T-6 = Siam weed compost (SWC) 20 ton ha- 1

$\mathrm{T}-7=$ SWC 15 ton ha- $1+200 \mathrm{~kg}$ urea ha- 1

T-8 = SWC 10 ton ha-1 + $200 \mathrm{~kg}$ urea ha-1

$\mathrm{T}-9=$ SWC 5 ton ha- $1+200 \mathrm{~kg}$ urea ha- 1

$\mathrm{T}-10$ = Dry leaves compost (DLC) 20 ton ha-1

$\mathrm{T}-11=$ DLC15 ton ha- $1+200 \mathrm{~kg}$ urea ha- 1

$\mathrm{T}-12=$ DLC 10 ton ha- $1+200 \mathrm{~kg}$ urea ha- 1

$\mathrm{T}-13=$ DLC 5 ton ha- $1+200 \mathrm{~kg}$ urea ha-1

Each treatment was replicated 5 times. Data was analyzed using ANOVA at 95\% confidence level. When there were significant differences, treatment mean was analyzed using Duncan's Multiple Range Test (DMRT) 5\%.

\section{B. Composting Procedure}

Wedelia and Siam weed composts were prepared by slicing into approximately $5 \mathrm{~cm}$ size of $50 \mathrm{~kg}$ of the biomass. The biomass, then, was put into wood box and sprayed with EM-4 solution using Knapsack spayer. The mixture was covered with transparent plastic. The mixture was incubated for 6 weeks and water was added when necessary to maintain its moisture. Every week the mixture was reversed to maintain supply of oxygen to the mixture. Dry leaves compost was made by adding $200 \mathrm{~kg}$ of grinded dry leaves, $75 \mathrm{~kg}$ fresh cattle manure, and $3 \mathrm{~kg}$ fine rice bran into wood box. The mixture was sprayed with EM-4 solution using Knapsack sprayer, then, was covered with thick black plastic and incubated for 6 weeks. The mixture was reversed every weeks and compost was considered mature when its color turned in dark.

\section{Growing Media Preparation}

Soil used in this experiment was Ultisol from Kandang Limun Village, Bengkulu, Indonesia. Soil sample was collected from top soil (0-20 cm depth) and air-dried, sieved through $5 \mathrm{~mm}$ mesh screen. A week before planting date, 10 $\mathrm{kg}$ of soil sample was mixed with compost according to each treatment into $25-\mathrm{kg}$ polybag.

\section{Chili Pepper Cultivation}

Chili pepper used in this experiment was H13 strain resulting from crossing of $\mathrm{C} 1008$ and IPBC120 strains. Chili pepper seed was saturated with warm water for 24 hours, then, was germinated in moist paper for 3 days. After germination, shoot was transferred to $10 \times 15 \mathrm{~cm}$ polybag containing top soil, manure, and sand at volume ratio of $2: 1: 1$. Ten grains of Carbofuran insecticide $30 \%$ were applied to each polybag. After 4 weeks, chili pepper seedlings were transferred into $25-\mathrm{kg}$ polybag previously treated with compost according to each treatment. Urea was applied 2 days after planting date. During the experiment, soil in the polybag was maintained moist by watering if necessary. Chili pepper fruit was harvested approximately 70 days after transplanting (more than $60 \%$ of chili fruit turned red). Harvesting was completed 8 times. Variables observed in this experiment including plant height, dichotomous height, stem diameter, canopy width, root dry weight per plant, fruit length, fruit diameter, weight per fruit, fresh fruit weight per plant, flowering time, and harvesting time.

\section{RESULT AND DISCUSSION}

\section{A. Effects of Compost and Nitrogen Fertilizer on Chili Pepper Growth}

Analysis of variance on chili pepper growth variables shows that compost and nitrogen fertilizer (urea) do not give significant effects on all of the variables observed. However, Table 1 indicates that in general, application of nitrogen fertilizer at rate $200 \mathrm{~kg}$ ha- 1 provides better growth of chili pepper as indicated in all the variables observed. This is related to rate of nitrogen availability for plant growth. Compost is characteristically slower release fertilizer than urea [15]. Nitrogen from urea, on the other hand, will be available very fast as it is applied to the soil. However, plant nutrient from compost will be slowly available in latter season.

Table 1 also shows that additional of nitrogen to compost tends to give worse growth on chili pepper and higher rate of compost is affected more than that of lower rate. This might be associated to microbial immobilization of nitrogen at earlier stage of chili pepper growth. Soil ammonium initially decreases at first 20-40 days due to immobilization after application of manure as reported by [16]. The effect is expected to lessen as season goes on.

TABLE I

EFFECTS OF COMPOST AND NITROGEN FERTILIZER ON CHILI PEPPER GROWTH VARIABLES

\begin{tabular}{lllllll}
\hline $\begin{array}{l}\text { Treatment } \\
\text { Compost } \\
\left(\text { ton ha }^{-1}\right)\end{array}$ & $\begin{array}{l}\text { Urea } \\
\left(\mathrm{kg} \mathrm{ha}^{-1}\right)\end{array}$ & $\begin{array}{l}\text { PH } \\
(\mathrm{cm})\end{array}$ & $\begin{array}{l}\text { DH } \\
(\mathrm{cm})\end{array}$ & $\begin{array}{l}\text { SD } \\
(\mathrm{mm})\end{array}$ & $\begin{array}{l}\text { CW } \\
(\mathrm{cm})\end{array}$ & $\begin{array}{l}\text { RDW } \\
(\mathrm{g})\end{array}$ \\
\hline- & 200 & 82.8 & 34.8 & 8.2 & 52.4 & 7.5 \\
WDC-20 & - & 68.4 & 31.3 & 8.57 & 44.2 & 6 \\
WDC-15 & 200 & 56.8 & 26.6 & 7.98 & 41.4 & 4.9 \\
WDC-10 & 200 & 68 & 29.2 & 7.58 & 42.8 & 3.9 \\
WDC-5 & 200 & 63.4 & 29.4 & 7.95 & 53 & 6 \\
SWC-20 & - & 52.8 & 28 & 8.2 & 47 & 6.3 \\
SWC-15 & 200 & 49.2 & 29.5 & 8.49 & 42.8 & 6.1 \\
SWC-10 & 200 & 49.2 & 25 & 6.79 & 41.2 & 3.5 \\
SWC-5 & 200 & 59.2 & 29.6 & 8.8 & 54.6 & 5.5
\end{tabular}




\begin{tabular}{lllllll} 
DLC-20 & - & 56.2 & 31 & 7.91 & 50 & 6.3 \\
DLC-15 & 200 & 58.2 & 31 & 6.84 & 42 & 6.2 \\
DLC-10 & 200 & 62.8 & 28.6 & 8.41 & 52.8 & 6.1 \\
DLC-5 & 200 & 53.4 & 28.6 & 7.32 & 36.4 & 6.1 \\
\hline
\end{tabular}

WDC=Wedelia Compost; SWC=Siam Weed Compost; DLC=Dry Leaves Compost; $\mathrm{PH}=$ Plant Height; $\mathrm{DH}=$ Dichotomous Height; $\mathrm{SD}=$ Stem Diameter; CW=Canopy Width; RDW=Root Dry Weight per Plant

TABLE II

EFFECTS OF COMPOST AND NITROGEN FERTILIZER ON CHILI PEPPER GROWTH VARIABLES

\begin{tabular}{|c|c|c|c|c|c|c|c|}
\hline \multicolumn{8}{|l|}{ Treatment } \\
\hline $\begin{array}{l}\text { Compost } \\
\text { (ton ha- } \mathrm{ha}^{-1}\end{array}$ & $\begin{array}{l}\text { Urea } \\
\left(\mathrm{kgha}^{-1}\right)\end{array}$ & $\begin{array}{l}\text { FT } \\
\text { (DAT) }\end{array}$ & $\begin{array}{l}\text { HT } \\
\text { (DAT) }\end{array}$ & $\begin{array}{l}\mathrm{FL} \\
(\mathrm{cm})\end{array}$ & $\begin{array}{l}\text { FD } \\
(\mathrm{cm})\end{array}$ & $\begin{array}{l}\text { WF } \\
\text { (g) }\end{array}$ & $\begin{array}{l}\text { FFW } \\
\text { (g) }\end{array}$ \\
\hline - & 200 & $28 \mathrm{ef}$ & 92 & $11.2 \mathrm{abcd}$ & 0.62 & 3.3 & $69.8 \mathrm{ab}$ \\
\hline WDC-20 & - & $27 \mathrm{f}$ & 87.2 & $12.2 \mathrm{a}$ & 0.67 & 2.9 & $84.3 \mathrm{a}$ \\
\hline WDC-15 & 200 & $27 \mathrm{f}$ & 83.4 & $11.8 \mathrm{abc}$ & 0.62 & 3 & $64.0 \mathrm{ab}$ \\
\hline WDC- 10 & 200 & $32 \mathrm{bcdef}$ & 87 & $11.7 \mathrm{abc}$ & 0.61 & 2.9 & $47.4 \mathrm{ab}$ \\
\hline WDC-5 & 200 & $29 \mathrm{def}$ & 85.4 & $10.6 \mathrm{~cd}$ & 0.55 & 2.9 & $30.5 \mathrm{~b}$ \\
\hline SWC-20 & - & $30 \mathrm{cdef}$ & 85.2 & $12.0 \mathrm{ab}$ & 0.69 & 3.3 & $80.0 \mathrm{a}$ \\
\hline SWC-15 & 200 & $33 \mathrm{bcdef}$ & 86 & $11.7 \mathrm{abc}$ & 0.64 & 3 & $88.3 \mathrm{a}$ \\
\hline SWC-10 & 200 & $42 \mathrm{a}$ & 82.2 & $11.4 \mathrm{abcd}$ & 0.64 & 3 & $53.7 \mathrm{ab}$ \\
\hline SWC-5 & 200 & 31 bcdef & 80.8 & $10.3 \mathrm{~d}$ & 0.65 & 2.9 & $28.2 \mathrm{~b}$ \\
\hline DLC-20 & - & $37 a b c$ & 86 & $11.6 \mathrm{abcd}$ & 0.64 & 2.7 & $47.6 \mathrm{ab}$ \\
\hline DLC-15 & 200 & 35 abcde & 83 & $11.3 \mathrm{abcd}$ & 0.62 & 2.7 & $63.3 \mathrm{ab}$ \\
\hline DLC-10 & 200 & $38 \mathrm{ab}$ & 79 & $11.3 \mathrm{abcd}$ & 0.61 & 2.9 & $56.9 \mathrm{~b}$ \\
\hline DLC-5 & 200 & $36 \mathrm{abcd}$ & 85.8 & $10.9 \mathrm{bcd}$ & 0.61 & 3.3 & $32.7 \mathrm{~b}$ \\
\hline
\end{tabular}

WDC $=$ Wedelia Compost; SWC $=$ Siam Weed Compost; DLC=Dry Leaves Compost; $\mathrm{FT}=$ Flowering Time; HT=Harvesting Time; FL=Fruit Length;FD=Fruit Diameter; WF=Weight per Fruit; FFW=Fresh Fruit Weight per Plant; DAT=Days After Transplanting; means followed by the same letters within column is significantly difference.

\section{B. Effects of Compost and Nitrogen Fertilizer on Yield Component of Chili Pepper}

Analysis of variance on yield component variables of chili pepper shows that compost and nitrogen fertilizer give significant differences on flowering time. fruit length and fresh fruit weight per plant. Different pattern of compost and nitrogen fertilizer effects is observed on yield component variables as on growth variables of chili pepper. Better development of chili pepper is observed when it is fertilized with compost as indicated in all yield variables seen in Table 2. As season goes on. decomposition of compost will supply nutrient and improve other soil chemical. physical. and biological properties. Application of compost increased level of soil nitrogen. phosphorus. calcium. potassium. magnesium and other soil properties [17] [18]. Addition of compost also significantly increased fresh and dry weight of tomato cultivated in sandy soil [19]. On the other hand. chili pepper fertilized with urea alone only provides nitrogen without significant improvement of other soil properties.

Table 2 also indicates that application Wedelia and Siam weed composts at rate 20 ton ha- 1 increase fruit length by $8.9 \%$ and $7.1 \%$. respectively in comparison to that of $200 \mathrm{~kg}$ urea ha-1. Also. chili pepper fertilized with Wedelia and Siam weed composts has $20.8 \%$ and $14.6 \%$ higher fresh fruit weight per plant. respectively as compared to that fertilized with $200 \mathrm{~kg}$ urea ha-1. Similar response is observed on flowering time. harvesting time. fruit diameter and weight per plant. This indicates that Wedelia compost and Siam weed compost at rate 200 ton ha-1 are able to substitute fertilization of $200 \mathrm{~kg}$ urea ha-1. Experiment reported by [11] suggested that Wedelia compost was able to substitute nitrogen fertilizer for pak choi (Brassica oleracea L.).

\section{CONCLUSIONS}

Application of composts with or without addition of nitrogen fertilizer gives similar responses on the growth of chili pepper. However. chili pepper fertilized with nitrogen fertilizer at rate $200 \mathrm{~kg}$ urea ha- 1 tends to have better growth performance as compared to other treatments. The opposite is observed on yield components of chili pepper. Wedelia and Siam weeds compost at rate 20 ton ha- 1 tends to give better yield of chili pepper as compared to application of nitrogen fertilizer alone. This result indicates that Wedelia and Siam weed composts are able to substitute nitrogen fertilizer.

\section{REFERENCES}

[1] A. Majid. "Peningkatan efisiensi pemupukan fosfat dan hasil kedelai dengan menekan adsorpsi $\mathrm{P}$ maksimum akibat pemberian ameliuron pada Ultisol Jambi.” Doctor Diss. Universitas Padjadjaran. Bandung . 1998.

[2] R. Susanto. Dasar-Dasar Ilmu Tanah. Kaninsus. Yogyakarta. 2005.

[3] S. Brown and M. Cotton.. "Changes in soil properties and carbon content following compost application: Results of on-farm sampling." Compost Science \& Utilization vol. 19. no.2. pp. 87-96. 2011

[4] K.D. Smiciklas. P. M. Walker and T.R. Kelley. "Evaluation of compost for use as a soil amendment in corn and soybean production." Compost Science \& Utilization. vol. 16. no. 3. pp. 183191. 2008.

[5] C. Viti. E. Tatti. F. Decorosi. E. Lista. E. Rea. M. Tullio. E. Sparvoli. and L. Giovannetti. "Compost effect on plant growth-promoting rhizobacteria and mychorrhizal fungi population in maize cultivations." Compost Science \& Utilization. vol. 18. no.4. pp. 273281. 2010.

[6] T. T.T. Duong. C. Penfold and P. Marschner. "Amending soils of different texture with six compost types: Impact on soil nutrient availability. plant growth and nutrient uptake." Plant Soil vol. 354. pp.197-209. 2012

[7] T.J. Butler. D. C. Weindorf. K. J. Han. and J.P. Muir. "Dairy manure compost quality effects on corn silage and soil properties." Compost Science \& Utilization. vol. 17. no 1. pp18-24. 2009.

[8] R.D.M. Simanungkalit. Prospek pupuk organik dan pupuk hayati di Indonesia. Balai Besar Litbang Sumberdaya Lahan Pertanian. Badan Pengembangan dan Penelitian. Bogor. 2006.

[9] J.P. Muir. T. Butler. T. J. Helton. and M. L. McFarland. "Dairy manure compost application rate and timing influence Bermuda grass yield and nutrient concentration." Crop Science. vol. 50. pp. 21332139. 2010.

[10] E. Supriyono. Winantuningsih. Sutopo. and A. Widyaningrum. "Pemanfaatan enceng gondok (Eichornia crassipes) sebagai pupuk dengan mempercepat pengomposan pada pertanaman kacang tanah." in Proc. Konferensi XIII Himpunan Ilmu Gulma Indonesia (HIGI. pp. 313-316. Yogyakarta. Indonesia 20-21 July 2005.

[11] N. Setyowati. U. Nurjanah and D. M. Four. "Singapore daisy (Wedelia trilobata L.) manure as inorganic nitrogen fertilizer substitution in pak choi (Brassica oleracea L.)." in Proceeding of the 2nd Internasional Symposium on Food Security. Agricultur Development \& Environmental Conservation in Southeast and East Asia. Bogor. September 4-6. 2007.

[12] N. Setyowati. U. Nurjannah and D. Haryanti. "Gulma tusuk konde (Wedelia trilobata) dan kirinyu (Chromolaena orodata) sebagai pupuk organik pada sawi." Akta Agrosia. vol. II. no. 1. pp. 47-56. 2008.

[13] Suntoro. Syekhfani. E. Hardayanto. and Soemarno. "Penggunaan bahan pangkas kriyu (Cromalaena ordata) untuk meningkatkan ketersediaan P. K. Ca. dan Mg pada Oxic Dystrudepten di Jumapolo. Karangayar Jawa Tengah”. Agritivia. 2001. 
[14] E. Maftu'ah. S. Asikin. and A. Najib. "Potensi gulma Cromolaena odorata dan Agerathum conyzoides sebagai sumber pupuk $\mathrm{N}$ dan $\mathrm{P}$ untuk menuju sistem pertanian organic." in Proc. Konferensi Nasional XVII Himpunan Ilmu Gulma Indonesia. Yogyakarta 20-21 July 2005.

[15] A. Emedinta. "Pengaruh taraf pupuk organik yang diperkaya terhadap pertumbuhan jagung manis dan sifat kimia tanah pada Latosol di Darmaga." Skripsi. Fakultas Pertanian. Institut Pertanian. Bogor. 2004

[16] M. Burger and R.T. Venterea. "Nitrogen immobilization and mineralization kinetics of cattle. hog. and turkey Manure applied to soil.” Soil Sci. Soc. Am. J. vol.72. pp.1570-1579. 2008
[17] A. L. Wright. T. L. Provin. F. M. Hons. D. A. Zuberer. and R.H. White. "Compost source and rate effects on soil macronutrient availability under Saint Augutine grass and Bermuda grass turf." Compost Science \& Utilization. vol. 15. np. 1. pp.22-28. 2007

[18] E.P. Jouquet. E. Bloquel. T. T. Doan. M. Ricoy. D. Orange. C. Rumpel. and T.T. Duc. "Do compost and vermicompost improve macronutrient retention and plant growth in degraded tropical soil?" Compost Science \& Utilization. vol 19. no.1. pp.15-24. 2011

[19] E. Arthur. W. Cornelis. and F. Razzaghi. "Compost amendment to sandy soil affects soil properties and greenhouse tomato productivity." Compost Science \& Utilization. vol. 20. no. 4. pp. 215-22.2012 